\title{
Neonatal healthcare-associated infections in Brazil: systematic review and meta-analysis
}

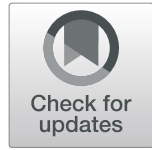

Felipe Teixeira de Mello Freitas ${ }^{1,2^{*}}$ (D, Anna Paula Bise Viegas ${ }^{3}$ and Gustavo Adolfo Sierra Romero ${ }^{4}$

\begin{abstract}
Background: Healthcare-associated infections (HAl) are important causes of neonatal morbidity and mortality in developing countries. We reviewed the incidence and the pathogens involved in HAl among infants admitted to neonatal intensive care units (NICU) in Brazil.

Methods: A search was conducted in the MEDLINE, LILACS and SciELO databases from January 1995 to October 2019. Two authors scrutinized potential articles independently, after one author selected them from screening abstracts from every article flagged as related to neonatal HAl. Then, they were included in the review if they met our inclusion criteria. The studies were evaluated based on a quality score proposed by the authors, rated 0 to 1 , with 1 point as the best quality rate. Pooled estimates and 95\% confidence intervals ( $95 \% \mathrm{Cl}$ ) for HAl cumulative incidence and incidence density were calculated, when the same denominators were available, using meta-analysis. A quality effect was applied to the models using the MetaXL software. Heterogeneity was assessed using $P$ statistics and the Cochran's Q test.

Results: Of a total of 5596 citations identified, 15 studies met the inclusion criteria for this review, which comprised 24,408 patients and 312,744 patient-days. Quality of the studies varied between 0.36 and 1 according to the adopted score, and six (40.0\%) studies presented a score of 1. Pooled HAl incidence was 36.1 (95\% Cl 22.8-50.7) infections and 26.3 (95\% Cl 18.4-35.0) infected patients per 100 patients. Pooled HAl incidence density was 23.5 (95\% Cl 16.3-33.9) per 1000 patient-days. Pooled incidence density rates of bloodstream infection and ventilatorassociated pneumonia were 13.1 per 1000 catheter-days (95\% Cl 4.3-40.1) and 7.9 per 1000 ventilator-days (95\% Cl 1.1-55.5), respectively. A high degree of heterogeneity was observed in all models $\left(I^{2}>98 \%\right.$ and Cochran's $Q$ test with $p<0.05)$. Coagulase-negative Staphylococci (32.1\%), Staphylococcus aureus (13.8\%) and Klebsiella spp. (12.4\%) were the most prevalent causative bacterial pathogens.

Conclusions: The findings show high incidence of neonatal HAI in Brazilian NICU; therefore, efforts to standardize the collection and notification of HAl are needed in order to strengthen surveillance in the country and implement preventive measures, routine assessment, and close monitoring of neonates.
\end{abstract}

Keywords: Healthcare-associated infections, Neonatal sepsis, Meta-analysis, Brazil

\footnotetext{
* Correspondence: felipetmf@gmail.com

'Escola Superior de Ciências da Saúde, Fundação de Ensino e Pesquisa em

Ciências da Saúde, Brasilia, Brazil

${ }^{2}$ Hospital Materno Infantil de Brasília, Secretaria de Estado de Saúde do

Distrito Federal, Brasilia, Brazil

Full list of author information is available at the end of the article
}

(c) The Author(s). 2021 Open Access This article is licensed under a Creative Commons Attribution 4.0 International License, which permits use, sharing, adaptation, distribution and reproduction in any medium or format, as long as you give appropriate credit to the original author(s) and the source, provide a link to the Creative Commons licence, and indicate if changes were made. The images or other third party material in this article are included in the article's Creative Commons licence, unless indicated otherwise in a credit line to the material. If material is not included in the article's Creative Commons licence and your intended use is not permitted by statutory regulation or exceeds the permitted use, you will need to obtain permission directly from the copyright holder. To view a copy of this licence, visit http://creativecommons.org/licenses/by/4.0/ The Creative Commons Public Domain Dedication waiver (http://creativecommons.org/publicdomain/zero/1.0/) applies to the data made available in this article, unless otherwise stated in a credit line to the data. 


\section{Background}

Brazil reduced infant mortality from 47.1 deaths per 1000 live births in 1990 to 15.3 deaths per 1000 live births in 2011, and thus achieved the fourth United Nations Millennium Goal [1, 2]. Most of the improvement was concentrated on post-neonatal mortality, which reduced at a rate of $8.1 \%$ per year from 1990 to 2007, whereas neonatal mortality reduced in a slower pace, $3.2 \%$ per year in the same period [3]. Thus, the proportion of neonatal mortality to mortality under the age of one has relatively increased, increasing from $49 \%$ in 1990 to $71 \%$ in 2015 [2]. Brazil has developed a new agenda, focused on actions to prevent neonatal mortality, to accelerate the reduction in infant mortality rates to as low as 10 deaths per 1000 live births by 2030, according to United Nations Sustainable Development Goals [4].

According to the national mortality system, the main conditions responsible for most of neonatal deaths in Brazil are complications associated with premature birth and low-birth weight, congenital anomalies, perinatal asphyxia, and infection [2]. Neonatal sepsis is one of the main causes of hospitalization and death in neonatal intensive care units (NICU) [5], and is considered healthcare-associated when infections are related to the care provided to pregnant women and neonates. There are two patterns of disease: early-onset neonatal sepsis (EOS) and late-onset neonatal sepsis (LOS). EOS is variably defined as occurring within $48-72 \mathrm{~h}$ after birth, and is related to care provided to women during gestation and delivery. In these cases, microorganisms are of maternal origin, acquired hours or days before or during delivery from the birth canal, and neonates may have a history of prolonged rupture of membranes, preterm onset of labor, chorioamnionitis, and peripartum maternal fever [6]. LOS is defined as occurring during 4-90 days of life, and is caused by microorganisms acquired during medical care and related to prematurity and low birth weight, prolonged use of intravascular access, mechanical ventilation, total parenteral nutrition, and exposure to broad spectrum antibiotics [7].

A national survey of healthcare-associated infections (HAI) was performed in 1994, and estimated a prevalence of HAI of $14.4 \%$ in NICU [8]. That triggered infection control policies, which culminated with a federal law making infection control compulsory in every hospital in the country in 1997 [9]. The first surveillance system for HAI in Brazil was developed in 2004, by the State of São Paulo, covering its territory [10] and in 2011 a national system was developed [11]. The system is dependent of notifications from a variety of hospitals, with different levels of complexity and no critical appraisal of the reliability and quality of the information reported has been performed so far. Moreover, as $98 \%$ of births occur in the hospital setting in Brazil [12], and because of the expansion of neonatal intensive care in the country in the last decades, HAI may account for a large proportion of neonatal deaths attributable to infection. Therefore, we decided to conduct a comprehensive systematic review and meta-analysis study, aiming to assess the incidence of neonatal HAI and identify their causative pathogens and their antimicrobial resistance profile in Brazilian NICU. This knowledge is essential to promote better policies and implement strategies to reduce neonatal mortality in the country.

\section{Methods}

\section{Search strategy and inclusion criteria}

This systematic review and meta-analysis aimed to identify studies on the epidemiology of neonatal HAI in Brazil: the proportion of EOS and the incidence of LOS of hospital origin. There was interest in the main sites of infection and rates of bloodstream infection (BSI) related to central venous catheters (CVC) and ventilator associated pneumonia (VAP), as well as in searching for the main microorganisms isolated in relevant microbiological samples and their antimicrobial resistance profile.

The Preferred Reporting Items for Systematic Reviews and Meta-analyses (PRISMA) guidelines were followed to perform this systematic review and meta-analysis [13]. A search with no language restriction was conducted in the online Medical Literature Analysis and Retrieval System (MEDLINE) for reports published between January 1995 and October 2019. The following syntax was applied: ("Cross infection" [MeSH] OR "Hospital Infection" OR "Hospital Infections" OR "Nosocomial Infection" OR "Nosocomial Infections" OR "Healthcare associated infection" OR "Healthcare associated infections" OR "Healthcare-associated infection" OR "Healthcare-associated infections" OR "sepsis" OR "infection" OR "infections") AND (("Infant, newborn" [MeSH] OR "infant newborn" OR "newborn infant" OR "newborn infants" OR "neonate" OR "neonates" OR "newborn" OR "newborns" OR "neonatal" OR "infant, premature" OR "infant" OR "infants") OR ("Intensive care units" [MeSH] OR "Intensive care unit" OR "Intensive care units" OR "Intensive care" OR "Care Unit, Intensive" OR "Unit, Intensive Care") OR ("Intensive Care Units, Neonatal" [MeSH] OR "Newborn Intensive Care Unit" OR "Newborn Intensive Care Units" OR "Neonatal Intensive Care Unit" OR "Neonatal Intensive Care Units" OR "Neonatal Intensive Care" OR "Newborn Intensive Care" OR "NICU”)) AND ("Brazil" [MeSH] OR "Brazil" OR "Brazilian" OR "Brasil"). The same search strategy was applied to regional, the Latin America and Caribbean Health Sciences Literature (LILACS) and the Scientific Electronic Library Online (SciELO) databases. 
Articles were flagged if the title indicated that the study was related to neonatal HAI. Then one author reviewed the abstracts of the flagged articles and obtained the full text of potentially relevant studies that contained either full or partial data for proportions of HAI and the microbiological cause of these infections. Finally, each selected article was scrutinized by two researchers independently, and evaluated if it met the following inclusion criteria: 1) be conducted in Brazil; 2) present a sample including infants admitted to NICU, or infants with any invasive device (CVC or mechanical ventilation), or premature infants, or infants with birth weight $<1500 \mathrm{~g}$; 3) present a report of HAI incidence or prevalence rates. Possible divergences between researchers in their evaluation were resolved by consensus. The reference lists of all reviewed studies were also screened for further eligible publications. References in duplicate, studies reporting outbreaks, publications reporting the same data, and non-original studies were excluded from this review. In the case of multiple reports by the same authors or same unit with overlapping study dates, the most comprehensive report was included.

\section{Data extraction}

Extracted data included: authors; year of publication; place where the study was conducted; period of study; type of publication; study design; sample size; type of patient population; type of surveyed infection; surveillance methods; definitions used for diagnosis; reported infection incidence data and corresponding denominators; microbiological isolates. Microbiological data were only considered suitable for assessment when the number of bacterial isolates was reported.

\section{Quality score}

After in-depth review and data entry into a dedicated database, the selected studies were classified according to their quality based on a score created by the authors (Fig. 1). The score was based on five key areas of study methodology that may result in biases estimates: 1) use of HAI standardized definitions; 2) study design (crosssectional or longitudinal); 3) method of HAI case detection (passive or active); 4) sample size; 5) measure of rates (person-time or cumulative incidence). The score for each area ranged from 0 to 2, except for the last area, which ranged from 0 to 1 . In the end, the score was divided by 9 , the maximum possible score, for standardization, and the final score ranged from 0 to 1 , with 1 point as the best available quality.

\section{Statistical analysis}

Data from incidence studies were pooled and the results in the same unit were summarized. The incidence of

\section{QUALITY SCORE}

1. HAI* definitions
CDC** or ANVISA*** $=2$
Other $=1$
Not mentioned $=0$
2. Study design
Longitudinal $=2$
Cross-sectional $=1$
Not mentioned $=0$
3. HAI detection
Active search $=2$
Passive search $=1$
Not mentioned $=0$
4. Sample size
$>1000$ patients or $>10,000$ patient-days $=2$
$>500$ to 1000 patients or $>5,000$ to 10,000 patient-days $=1$
$\leq 500$ patients or $\leq 5,000$ patient-days $=0$
5. Measurement of $\mathbf{H A I}$ incidence
Person-time denominator $=1$
otal score by 9 , the maximum possible score. HAl Healthcare-
Prevention; ANVISA Agência Nacional de Vigilância Sanitária (Brazilian
Sanitary Agency)

either infections or infected patients refers to the number of infection episodes or infected patients per $100 \mathrm{pa}-$ tients admitted to the NICU, respectively, during the study period. Infection incidence density refers to number of infection episodes per 1000 patient-days or device-days.

Median values and ranges of cumulative incidence and incidence density were reported. For studies reporting the same outcome measures and using the same methods, the data were pooled when the appropriate denominator was available. Pooled proportions and incidence densities were calculated using the MetaXL 5.3, a tool for meta-analysis in Microsoft Excel ${ }^{\circ}$ [14]. Models were systematically applied with quality-effects estimator. Incidence and incidence density data were subjected to arcsine transformation to stabilize variance and prevent over or underestimation of study weights [15]. 
Heterogeneity was assessed using $I^{2}$ statistics (values of 25, 50 and $75 \%$ represented low, medium and high heterogeneity, respectively) and the Cochran's $\mathrm{Q}$ test when $p<0.05$.

The total numbers of pathogens reported from BSIs and their antimicrobial resistance profile were descriptively presented.

\section{Results}

Of a total of 5596 citations identified, 138 met the criteria for abstract review and 52 met the criteria for fulltext assessment, of which 15 met the inclusion criteria for this review, namely, Kawagoe, JY et al. 2001 [16]; Nagata, E et al. 2002 [17]; Pessoa-Silva, CL et al. 2004 [18]; Couto, RC et al. 2007 [19]; Távora, AC et al. 2008 [20]; Pereira, SM et al. 2009 [21]; Catarino, CF et al. 2012 [22]; Dal-Bó, K et al. 2012 [23]; Freitas, BA et al. 2012 [24]; Ventura, CM et al. 2012 [25]; Romanelli, RM et al. 2013 [26]; da Silva, AR et al. 2013 [27]; de Souza Rugolo, LM et al. 2014 [28]; Urzedo, JE et al. 2014 [29]; Freitas, FTM et al. 2019 [30] (Fig. 2).

\section{Characteristics of the studies included in the review}

The 15 studies comprised 24,408 patients (range from 203 to 6243; median of 866) and, although six studies did not report the number of patients-day, 312,744 patient-days (range from 1839 to 121,008; median of 14, 256) were included in the remaining nine studies. Quality of the studies varied between 0.36 and 1.0 according to the adopted score, and six (40.0\%) studies presented a score of 1 .

The studies were conducted between 1993 and 2016 in 14 Brazilian cities located in the following regions of the country, 10 (66.7\%), Southeast region; two (13.3\%), South region; two (13.3\%), Northeast region; one $(6.7 \%)$, Mid-west region. No studies were conducted in the North region. Data were collected from 28 NICU, 14 $(50.0 \%)$ of which were located in university hospitals, five $(17.8 \%)$ in public hospitals, four $(14.3 \%)$ in private hospitals, one (3.6\%) in a philanthropic hospital, and four (14.3\%) did not mention the type of hospital. Twelve studies $(80.0 \%)$ included all infants admitted to the NICU, two (13.3\%) included only infants < $1500 \mathrm{~g}$, and one $(6.7 \%)$ included only preterm infants. According to the definition of HAI, seven (46.7\%) studies reported the use of the American Centers for Disease Control and Prevention (CDC) [27], four (26.6\%) reported the use of the Brazilian Sanitary Agency (ANVISA) [28], two (13.3\%) did not report which definition they used, one (6.7\%) reported the use of both CDC and ANVISA definitions, and one (6.7\%) developed its own definition. Table 1 shows a summary of the characteristics of the assessed studies.

\section{Healthcare-associated infection incidence}

Regarding HAI, four studies did not differentiate between early and late-onset sepsis, six studies only

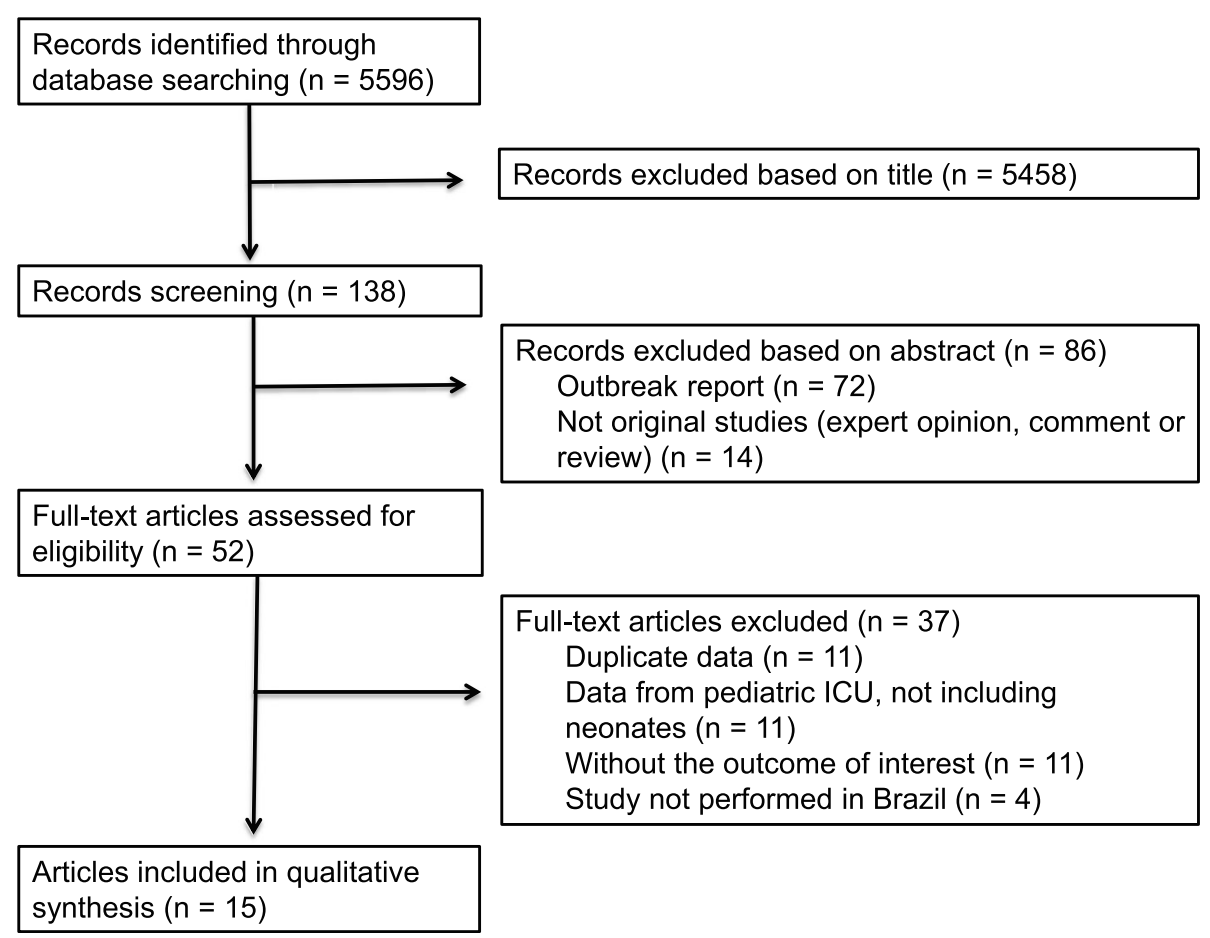

Fig. 2 Flowchart showing the search and study selection strategy 
Table 1 Characteristics of the assessed studies, neonatal healthcare-associated infections, Brazil

\begin{tabular}{|c|c|c|c|c|c|c|c|c|c|c|c|}
\hline $\begin{array}{l}\text { Authors/ } \\
\text { Publication } \\
\text { year }\end{array}$ & $\begin{array}{l}\text { Study } \\
\text { period }\end{array}$ & $\begin{array}{l}\text { Study } \\
\text { location }\end{array}$ & $\begin{array}{l}\text { Hospital } \\
\text { setting }\end{array}$ & $\begin{array}{l}\text { Target } \\
\text { population }\end{array}$ & $\begin{array}{l}\text { HAl } \\
\text { criteria }\end{array}$ & $\begin{array}{l}\text { Number } \\
\text { of } \\
\text { patients }\end{array}$ & $\begin{array}{l}\text { Number } \\
\text { of } \\
\text { patients- } \\
\text { day }\end{array}$ & $\begin{array}{l}\text { HAI } \\
\text { incidence } \\
\text { density* }\end{array}$ & $\begin{array}{l}\text { BSI-CVC } \\
\text { incidence } \\
\text { density* }\end{array}$ & $\begin{array}{l}\text { VAP } \\
\text { incidence } \\
\text { density* }\end{array}$ & $\begin{array}{l}\text { Quality } \\
\text { score }\end{array}$ \\
\hline $\begin{array}{l}\text { Kawagoe, JY } \\
\text { et al. } 2001\end{array}$ & $\begin{array}{l}\text { January } \\
1993 \text { to } \\
\text { December } \\
1997\end{array}$ & São Paulo & Private & $\begin{array}{l}\text { Every } \\
\text { newborn } \\
\text { admitted } \\
\text { to NICU }\end{array}$ & $\begin{array}{l}\text { CDC } \\
1988\end{array}$ & 1544 & 12,266 & 23.8 & NR & NR & 1 \\
\hline $\begin{array}{l}\text { Nagata, E } \\
\text { et al. } 2002\end{array}$ & $\begin{array}{l}\text { January } \\
1999 \text { to } \\
\text { March } \\
2000\end{array}$ & Londrina & University & $\begin{array}{l}\text { Every } \\
\text { newborn } \\
\text { admitted } \\
\text { to NICU }\end{array}$ & $\begin{array}{l}\text { CDC } \\
1988\end{array}$ & 225 & 1839 & 62 & 59.9 & 142.8 & 0.81 \\
\hline $\begin{array}{l}\text { Pessoa-Silva, } \\
\text { CL et al. } \\
2004\end{array}$ & $\begin{array}{l}\text { January } \\
1997 \text { to } \\
\text { December } \\
1998\end{array}$ & $\begin{array}{l}\text { Campinas, } \\
\text { Rio de } \\
\text { Janeiro, São } \\
\text { Paulo }\end{array}$ & $\begin{array}{l}\text { Private and } \\
\text { university }\end{array}$ & $\begin{array}{l}\text { Every } \\
\text { newborn } \\
\text { admitted } \\
\text { to NICU }\end{array}$ & $\begin{array}{l}\text { CDC } \\
1988\end{array}$ & 4878 & 60,048 & 18.0 & 25.3 & 7.9 & 1 \\
\hline $\begin{array}{l}\text { Couto, RC } \\
\text { et al. } 2007\end{array}$ & $\begin{array}{l}\text { January } \\
1993 \text { to } \\
\text { December } \\
2002\end{array}$ & $\begin{array}{l}\text { Belo } \\
\text { Horizonte }\end{array}$ & $\begin{array}{l}\text { Private and } \\
\text { university }\end{array}$ & $\begin{array}{l}\text { Every } \\
\text { newborn } \\
\text { admitted } \\
\text { to NICU }\end{array}$ & $\begin{array}{l}\text { CDC } \\
1988\end{array}$ & 6243 & 121,008 & 29.8 & 13.7 & 4.3 & 1 \\
\hline $\begin{array}{l}\text { Távora, AC } \\
\text { et al. } 2008\end{array}$ & $\begin{array}{l}\text { January } \\
2003 \text { to } \\
\text { December } \\
2003\end{array}$ & Fortaleza & University & $\begin{array}{l}\text { Every } \\
\text { newborn } \\
\text { admitted } \\
\text { to NICU }\end{array}$ & $\begin{array}{l}\text { CDC } \\
1988\end{array}$ & 948 & NR & NR & NR & NR & 0.63 \\
\hline $\begin{array}{l}\text { Pereira, SM } \\
\text { et al. } 2009\end{array}$ & $\begin{array}{l}\text { April } 2001 \\
\text { to } \\
\text { September } \\
2004\end{array}$ & $\begin{array}{l}\text { Rio de } \\
\text { Janeiro }\end{array}$ & Public & $\begin{array}{l}\text { Every } \\
\text { newborn < } \\
1500 \mathrm{~g}\end{array}$ & NR & 203 & NR & $N R$ & NR & NR & 0.45 \\
\hline $\begin{array}{l}\text { Catarino, CF } \\
\text { et al. } 2012\end{array}$ & $\begin{array}{l}\text { January } \\
2010 \text { to } \\
\text { December } \\
2010\end{array}$ & $\begin{array}{l}\text { Rio de } \\
\text { Janeiro }\end{array}$ & Public & $\begin{array}{l}\text { Every } \\
\text { newborn } \\
\text { admitted } \\
\text { to NICU }\end{array}$ & ANVISA & 384 & NR & NR & 14.3 & NR & 0.63 \\
\hline $\begin{array}{l}\text { Dal-Bó, K } \\
\text { et al. } 2012\end{array}$ & $\begin{array}{l}\text { January } \\
2010 \text { to } \\
\text { December } \\
2010\end{array}$ & Tubarão & Philanthropic & $\begin{array}{l}\text { Every } \\
\text { newborn } \\
\text { admitted } \\
\text { to NICU }\end{array}$ & $\begin{array}{l}\text { CDC } \\
2008 \\
\text { and } \\
\text { ANVISA }\end{array}$ & 239 & NR & NR & NR & NR & 0.72 \\
\hline $\begin{array}{l}\text { Freitas, BA } \\
\text { et al. } 2012\end{array}$ & $\begin{array}{l}\text { January } \\
2008 \text { to } \\
\text { December } \\
2010\end{array}$ & Viçosa & Public & $\begin{array}{l}\text { Every } \\
\text { preterm } \\
\text { newborn }\end{array}$ & ANVISA & 267 & NR & NR & NR & NR & 0.54 \\
\hline $\begin{array}{l}\text { Ventura, CM } \\
\text { et al. } 2012\end{array}$ & $\begin{array}{l}\text { March } \\
2009 \text { to } \\
\text { August } \\
2009\end{array}$ & Recife & Public & $\begin{array}{l}\text { Every } \\
\text { newborn } \\
\text { admitted } \\
\text { to NICU }\end{array}$ & NR & 218 & 2958 & 23.6 & NR & NR & 0.36 \\
\hline $\begin{array}{l}\text { Romanelli, } \\
\text { RM et al. } \\
2013\end{array}$ & $\begin{array}{l}\text { January } \\
2008 \text { to } \\
\text { December } \\
2009\end{array}$ & $\begin{array}{l}\text { Belo } \\
\text { Horizonte }\end{array}$ & University & $\begin{array}{l}\text { Every } \\
\text { newborn } \\
\text { admitted } \\
\text { to NICU }\end{array}$ & $\begin{array}{l}\text { CDC } \\
2008\end{array}$ & 886 & 14,256 & 22.7 & 18.1 & 5.7 & 1 \\
\hline $\begin{array}{l}\text { da Silva, AR } \\
\text { et al. } 2013\end{array}$ & $\begin{array}{l}\text { January } \\
2010 \text { to } \\
\text { June } 2012\end{array}$ & $\begin{array}{l}\text { Rio de } \\
\text { Janeiro }\end{array}$ & Private & $\begin{array}{l}\text { Every } \\
\text { newborn } \\
\text { admitted } \\
\text { to NICU }\end{array}$ & ANVISA & 765 & 3051 & 18.7 & NR & NR & 0.72 \\
\hline $\begin{array}{l}\text { de Souza } \\
\text { Rugolo, LM } \\
\text { et al. } 2014\end{array}$ & $\begin{array}{l}\text { January } \\
2006 \text { to } \\
\text { December } \\
2008\end{array}$ & $\begin{array}{l}\text { Botucatu, } \\
\text { Campinas, } \\
\text { Porto } \\
\text { Alegre, } \\
\text { Ribeirão } \\
\text { Preto, Rio } \\
\text { de Janeiro, } \\
\text { São Paulo }\end{array}$ & University & $\begin{array}{l}\text { Every } \\
\text { newborn < } \\
1500 \mathrm{~g}\end{array}$ & $\begin{array}{l}\text { Own } \\
\text { criteria }\end{array}$ & 1507 & NR & NR & $N R$ & NR & 0.81 \\
\hline $\begin{array}{l}\text { Urzedo, JE } \\
\text { et al. } 2014\end{array}$ & $\begin{array}{l}\text { January } \\
1997 \text { to }\end{array}$ & Uberlândia & University & $\begin{array}{l}\text { Every } \\
\text { newborn }\end{array}$ & $\begin{array}{l}\text { CDC } \\
2008\end{array}$ & 4615 & 62,412 & 17.6 & 17.3 & 3.2 & 1 \\
\hline
\end{tabular}


Table 1 Characteristics of the assessed studies, neonatal healthcare-associated infections, Brazil (Continued)

\begin{tabular}{|c|c|c|c|c|c|c|c|c|c|c|c|}
\hline $\begin{array}{l}\text { Authors/ } \\
\text { Publication } \\
\text { year }\end{array}$ & $\begin{array}{l}\text { Study } \\
\text { period }\end{array}$ & $\begin{array}{l}\text { Study } \\
\text { location }\end{array}$ & $\begin{array}{l}\text { Hospital } \\
\text { setting }\end{array}$ & $\begin{array}{l}\text { Target } \\
\text { population }\end{array}$ & $\begin{array}{l}\text { HAI } \\
\text { criteria }\end{array}$ & $\begin{array}{l}\text { Number } \\
\text { of } \\
\text { patients }\end{array}$ & $\begin{array}{l}\text { Number } \\
\text { of } \\
\text { patients- } \\
\text { day }\end{array}$ & $\begin{array}{l}\text { HAI } \\
\text { incidence } \\
\text { density* }\end{array}$ & $\begin{array}{l}\text { BSI-CVC } \\
\text { incidence } \\
\text { density* }\end{array}$ & $\begin{array}{l}\text { VAP } \\
\text { incidence } \\
\text { density* }^{*}\end{array}$ & $\begin{array}{l}\text { Quality } \\
\text { score }\end{array}$ \\
\hline & $\begin{array}{l}\text { December } \\
2012\end{array}$ & & & $\begin{array}{l}\text { admitted } \\
\text { to NICU }\end{array}$ & & & & & & & \\
\hline $\begin{array}{l}\text { Freitas, FTM } \\
\text { et al. } 2019\end{array}$ & $\begin{array}{l}\text { January } \\
2014 \text { to } \\
\text { December } \\
2016\end{array}$ & Brasília & Public & $\begin{array}{l}\text { Every } \\
\text { newborn } \\
\text { admitted } \\
\text { to NICU }\end{array}$ & ANVISA & 1506 & 34,906 & 20.4 & 18.6 & NR & 1 \\
\hline
\end{tabular}

* Per 1000 patient-days or 1000 device-days

NR: Not reported

included LOS, and five studies differentiated EOS from LOS. Among these latter studies, the proportion of EOS ranged from 11.5 to $36.3 \%$. Ten studies reported the site of infection, excluding EOS when this information was available. There were 7570 episodes of LOS among these studies: 3925 (51.8\%) were BSIs, 877 (11.6\%) conjunctivitis, 605 (8.0\%) skin and soft tissue infections, 568 (7.5\%) pneumonia, 301 (4.0\%) ear, nose and mouth infections, 259 (3.4\%) necrotizing enterocolitis, 174 (2.3\%) urinary tract infections, $173(2.3 \%)$ vascular infections, 157 (2.1\%) meningitis, 131 (1.7\%) surgical site infections, 117 (1.6\%) omphalitis, and 283 (3.7\%) other episodes.

There was heterogeneity regarding how studies reported HAI cumulative incidence. Among 13 studies, it was possible to use the overall number of infections, while among 11 studies, it was possible to use the number of infected patients, as numerator, per 100 admitted patients for the study period.

The median incidence of HAI was 34.2 (range from 7.4 to 64.9 ) infections per 100 patients and 25.7 (range from 13.8 to 46.6) infected patients per 100 patients. Pooled incidence of overall HAI was 36.1 (95\% CI 22.850.7) infections per 100 patients and 26.3 (95\% CI 18.435.0) infected patients per 100 patients. A high degree of heterogeneity was observed between these studies $\left(I^{2}=\right.$ $99.5 \%, p<0.01$ and $I^{2}=98.9 \%, p<0.01$, respectively).

HAI incidence densities were reported in nine studies, with a median of 23.6 (range from 15.1 to 62.0) infections per 1000 patient-days. Pooled HAI incidence density was 23.5 (95\% CI 16.3-33.9) per 1000 patient-days. Seven studies reported BSI associated with CVC incidence density, with a median of 18.1 (range from 3.1 to 60.0) BSI per 1000 catheter-days. Pooled BSI-CVC incidence density was 13.1 per 1000 catheter-days (95\% CI 4.3-40.1). Five studies reported VAP incidence density, with a median of 5.7 (range from 3.2 to 142.8) VAP per 1000 ventilator-days. Pooled VAP incidence density was 7.9 per 1000 ventilator-days (95\% CI 1.1-55.5). A high degree of heterogeneity was detected in studies reporting HAI incidence density $\left(I^{2}=99.9 \%, p<0.01\right)$, BSI-CVC incidence density $\left(I^{2}=99.9 \%, p<0.01\right)$ and VAP incidence density $\left(I^{2}=99.9 \%, p<0.01\right)$. Forest plots graphs summarizing the pooled HAI incidence rates are shown in Fig. 3.

\section{HAl pathogens and their antimicrobial resistance profile}

Information on pathogens causing HAI was available from 12 studies. It resulted in 3803 bloodstream samples, and only one study differentiated EOS from LOS cultures. Gram-positive bacteria corresponded to 1944 (51.1\%) of the pathogens, $1523(40.1 \%)$ were gramnegative bacteria, and $336(8.8 \%)$ were fungi. Coagulasenegative staphylococci $(1275 ; 33.5 \%)$, Staphylococcus aureus (503; 13.2\%), Klebsiella sp. (456; 12.0\%), Candida sp. (227; 6.0\%), and Escherichia coli $(197 ; 5.2 \%)$ were the main pathogens identified. Table 2 shows a summary of the isolated pathogens.

Only eight studies reported antimicrobial resistance. Methicillin resistant $S$. aureus (MRSA) was reported in five studies, and ranged from 1.2 to $28.3 \%$ among S. aureus isolates. Only one study reported one single sample of vancomycin resistant Enterococcus sp. Enterobacteriaceae resistance to 3 rd-generation cephalosporin was reported in six studies, and ranged from 23.3 to $36.6 \%$ among Enterobacteriaceae isolates and was most common among Klebsiella spp. There were no reports of carbapenem resistant Enterobacteriaceae (CRE).

\section{Discussion}

This systematic review and meta-analysis study showed that endemic HAI represents a major burden and a safety issue for infants admitted in Brazilian NICU. A country-level estimate of neonatal HAI is reported, and pooled estimates showed that HAI incidence is $26.3 \%$ and BSI incidence density is 13.1 per 1000 CVC-day. The Brazilian Sanitary Agency has developed a network for HAI surveillance since 2011 that made the notification of HAI compulsory for every hospital in the country. Such a large surveillance system in such a diverse country is prone to inaccuracy due to the large variety of health services and their levels of complexity and capability to perform high quality surveillance. To date, there is no publicly available evaluation of this surveillance system that can critically appraise its results. 


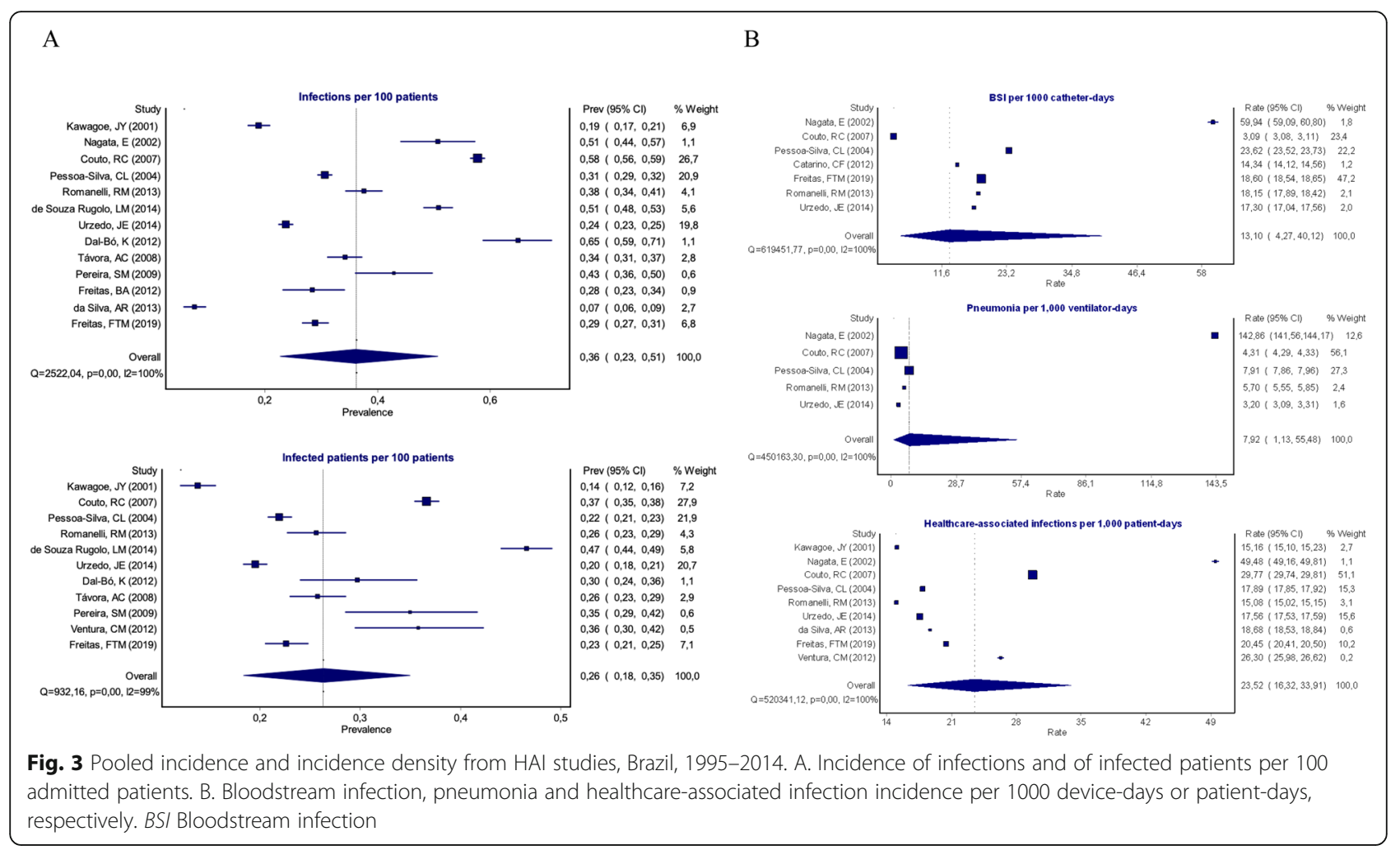

Table 2 The pathogens responsible for $\mathrm{HAl}$ in NICU, isolated from bloodstream from 12 studies, Brazil

\begin{tabular}{ll}
\hline Pathogens & $\mathbf{n}(\%)$ \\
\hline Coagulase-negative staphylococci & $1117(32.1)$ \\
Staphylococcus aureus & $482(13.8)$ \\
Klebsiella sp. & $431(12.4)$ \\
Unspecified gram negative rods & $293(8.4)$ \\
Escherichia coli & $192(5.5)$ \\
Candida sp. & $188(5.3)$ \\
Pseudomonas aeruginosa & $150(4.3)$ \\
Unspecified fungi & $120(3.4)$ \\
Enterobacter sp. & $115(3.3)$ \\
Acinetobacter sp. & $76(2.2)$ \\
Enterococcus sp. & $68(1.9)$ \\
Serratia marcescens & $61(1.8)$ \\
Proteus mirabilis & $48(1.4)$ \\
Streptococcus agalactiae & $46(1.3)$ \\
Others & $98(2.8)$ \\
TOTAL & $\mathbf{3 4 8 5}(100)$
\end{tabular}

The studies included were Kawagoe, JY et al.; Nagata, E et al.; Pessoa-Silva, CL et al.; Couto, RC et al.; Távora, AC et al.; Catarino, CF et al.; Dal-Bó, $\mathrm{K}$ et al.; Freitas, BA et al.; Romanelli, RM et al.; de Souza Rugolo, LM et al.; Urzedo, JE et al.; Freitas, FTM et al.
According to its first report, with data from 2011, the BSI rate in Brazilian NICU was 22.9 per 1000 catheterdays [11], and reached 7.5 per 1000 catheter-days in 2018 according to its last report, a decrease of $67.2 \%$, but the 90th percentile was still 15.5 per 1000 catheterdays [31]. This figure is lower than the pooled rate observed in the present study; however, the comparison of actual rates with our estimates are inadequate because our study spans a long period, from the initial milestones of hospital infection control in Brazil: the first reported outbreaks in nurseries, the first national HAI survey and legislation in the mid-1990s to the present day. During this period, there were several changes in the HAI definitions for surveillance and many advances in their control, with infection rates gradually decreasing. The data shown here are similar to those from the International Nosocomial Infection Control Consortium (INICC), which involved 48 NICU from middle- and low-income countries (18 from Latin America) and showed a pooled mean of 16.37 BSI per 1000 CVC-days [32]. Nevertheless, the figures presented here are higher than the average incidence rates in developed countries. In American NICU, the HAI rates were $1.3 \mathrm{BSI}$ per 1000 CVC-days and 0.9 VAP per 1000 ventilator-days [33]. In Germany, among very low birth weight infants, BSI incidence density rates were 8.6 per 1000 CVC-days and 2.7 VAP per 1000 ventilator-days [34]. 
Bloodstream was the most common site of infection, as reported elsewhere. Infants rarely manifest sepsis as a focal infection, which hinders the definition of a focal infection as pneumonia, for example. Possibly, the BSI rates are overestimated, and better definition of HAI in the neonatal period remains a challenge. Low prevalence of necrotizing enterocolitis, meningitis, and surgical site infection (SSI) was found. The possible explanation is that the surveillance definitions only consider necrotizing enterocolitis when there is a radiologic finding of intestinal wall suffering, excluding less severe cases. For meningitis, no study has reported the frequency of lumbar puncture, and if this is not an established practice in the NICU, many meningitis may go undetected, especially in very low birth weight infants. As for SSI, it was not reported whether the NICU performed surgery, as only NICU with high level of complexity perform neonatal surgery.

The microbiological data was not able to compare pathogens between EOS and LOS. The predominance of gram-positive cocci, such as coagulase-negative staphylococci (CoNS) and $S$. aureus, followed by gram-negative rods such as Klebsiella sp. or Escherichia coli, and a lower proportion of Candida sp., was the same profile reported by ANVISA [35] and reflects the LOS profile observed in developed countries [5,33]. This profile, of predominantly hospital-acquired pathogens, indicates the adoption of complex tertiary level neonatal care with a high rate of invasive device use.

The frequency of antimicrobial resistance was observed is close to that reported by ANVISA. The main concern in Brazilian nurseries is extended-spectrum $\beta$ lactamase (ESBL) producing organisms. Over a third of the Enterobacteriaceae were resistant to cephalosporins, and there was a relevant proportion of MRSA [35]. This profile possibly reflects the powerful selective pressure of inappropriate and prolonged use of antimicrobial drugs, specially 3rd and 4th generation cephalosporins, such as cefotaxime and cefepime that favor the emergence of ESBL and Candida spp. in hospital nurseries. No reports of CRE were found. Emergence of CRE in Brazilian NICU seems rarer than observed in adult intensive care units.

Limitations to this study include that although we opted to have a broad search to increase its sensitivity, we had only a single author to review a large number of abstracts. We acknowledge that this may risk losing potential articles to the systematic review, thus the procedure was carefully done twice. There was absence of representation of large geographic areas of Brazil due to the simple lack of reported data. We believe that HAI incidence may be underestimated, because more organized services, which are capable of performing high quality surveillance with better results, usually report their data. Moreover, there was a large heterogeneity between the studies, especially regarding sample size and the criteria used to define HAI. Some studies used the American National Healthcare Safety Network (NHSN) criteria from the CDC [36], while others used the Brazilian criteria from ANVISA [37]. Both criteria are similar, but the ANVISA criteria is more specific for clinical BSI because, in the absence of a positive blood culture, it defines sepsis according to a score using white blood cell count and reactive $\mathrm{C}$ protein despite physician prescription of antibiotics, unlike the CDC criteria. To cope with heterogeneity between studies, we preferred to apply a quality-effects estimator for meta-analysis, because unlike random-effects model, quality-effects method allows to incorporate study quality assessments into the pooled estimates. Furthermore, the quality-effects model leads to the maintenance of the correct coverage probability of the confidence interval, regardless of the level of heterogeneity, as well as a lower observed variance compared to the random effects model [38, 39]. As there is no quality score for studies addressing neonatal HAI, we decided to create our own score based on objective parameters. This quality score was aimed at simplicity and ease of application and reproducibility by different researchers. Similar approaches using MetaXL qualityeffects models have been used successfully in different studies [40]. Moreover, the quality-effects model is robust to subjectivity in quality assessment because it tolerates a fair amount of variability in reproducibility related to who assesses the quality of the studies. The reason is the way quality information is used; it does not require any information on the direction and magnitude of the bias induced by quality deficiencies. The credibility rank is the relative probability that the study is credible related to the best study in the meta-analysis, thus scale independent. Previous studies have demonstrated that despite a wide variation in the quality of input studies, the error and coverage of the estimator remain superior to the random-effects model [38, 39]. Thus, to improve neonatal infection research and promote transparency, clarity, and comparability of scientific reporting, urgent standards and criteria to report neonatal infection are needed to synthetize robust evidence to inform public health interventions. A recent extension of the Strengthening the Reporting of Observational Studies in Epidemiology (STROBE) statement has been published for Newborn Infection (STROBE- NI), which can be useful in the coming years [41].

\section{Conclusions}

In conclusion, a high burden of HAI was observed among Brazilian studies, which affects the most vulnerable group of infants, usually preterm and low birth weight, or those with complex congenital anomalies who 
need intensive care. This fact highlights the urgent need to prevent preterm birth as a strategy to reduce neonatal mortality. This is especially important in Brazil, where preterm birth has increased over the past years, reaching $11.9 \%$ of all births [42], twice the percentage observed in developed countries (5.5\%) [43]. Improving antenatal care, with special attention to poverty-related maternal conditions, such as infections during pregnancy, preeclampsia, gestational diabetes, vaginal bleeding, low body mass index, smoking, and alcohol or drug abuse would reduce preterm birth. Moreover, a decrease in the number of Caesarean sections would also contribute to reduce preterm birth in Brazil, where the rate of this type of delivery is one of the highest in the world (55\%) [44]. Additionally, there is an enormous gap between HAI rates in developed and developing countries, where there are constraints in staff and shortage of supplies and resources [45]. In middle-income countries as Brazil, where most births occur in the hospital setting and tertiary neonatal care with high rate of invasive device use has become more accessible, national estimates of HAI incidence can assist with prioritizing and evaluating effectiveness control measures such as quality improvement methods aimed at HAI prevention, including hand hygiene compliance, BSI prevention bundles, safe surgery, and antimicrobial stewardship programs.

\section{Abbreviations}

ANVISA: Agência Nacional de Vigilância Sanitária - Brazilian Sanitary Agency; BSI: Bloodstream infection; CDC: Centers for Disease Control and Prevention; CoNS: Coagulase-negative staphylococci; CRE: Carbapenem resistant Enterobacteriaceae; CVC: Central venous catheter; EOS: Early-onset neonatal sepsis; ESBL: Extended-spectrum $\beta$-lactamase; HAl: Healthcare-associated infection; INICC: International Nosocomial Infection Control Consortium; LILA CS: Latin America and Caribbean Health Sciences Literature; LOS: Late-onset neonatal sepsis; MEDLINE: Medical Literature Analysis and Retrieval System; MRSA: Methicillin resistant Staphylococcus aureus; NHSN: National Healthcare Safety Network; NICU: Neonatal Intensive Care Unit; PRISMA: Preferred Reporting Items for Systematic Reviews and Meta-analyses; SSI: Surgical site infection; SciELO: Scientific Electronic Library Online; STROBE-

NI: Strengthening the Reporting of Observational Studies in Epidemiology for Newborn Infection; VAP: Ventilator-associated pneumonia

\section{Acknowledgements}

Not applicable.

\section{Authors' contributions}

FTMF and GASR conceptualized the research idea and developed the manuscript framework. FTMF did the literature review and wrote the first draft. APBV contributed to the analysis of the literature and review. All authors read and approved the final manuscript.

\section{Funding}

English review of the manuscript was supported by research funds from the Fundação de Ensino e Pesquisa em Ciências da Saúde, Secretaria de Estado de Saúde do Distrito Federal, Brasilia, Brazil.

Availability of data and materials Not applicable.

\section{Declarations}

Ethics approval and consent to participate

Not applicable.

\section{Consent for publication}

Not applicable.

\section{Competing interests}

The authors declare that they have no competing interests.

\section{Author details}

${ }^{1}$ Escola Superior de Ciências da Saúde, Fundação de Ensino e Pesquisa em Ciências da Saúde, Brasilia, Brazil. ${ }^{2}$ Hospital Materno Infantil de Brasília, Secretaria de Estado de Saúde do Distrito Federal, Brasilia, Brazil. ${ }^{3}$ Secretaria de Vigilância em Saúde, Secretaria de Estado de Saúde do Distrito Federal, Brasilia, Brazil. ${ }^{4}$ Núcleo de Medicina Tropical, Faculdade de Medicina, Universidade de Brasília, Brasilia, Brazil.

Received: 7 December 2020 Accepted: 21 May 2021

Published online: 01 June 2021

\section{References}

1. Barros FC, Matijasevich A, Requejo JH, Giugliani E, Maranhão AG, Monteiro $C A$, et al. Recent trends in maternal, newborn, and child health in Brazil: progress toward millennium development goals 4 and 5 . Am J Public Health. 2010;100(10):1877-89. https://doi.org/10.2105/AJPH.2010.196816.

2. Brasil. Ministério da Saúde. Secretaria de Vigilância em Saúde. Departamento de Vigilância de Doenças e Agravos não Transmissíveis e Promoção da Saúde. Cap. 2: Evolução e principais causas da mortalidade na infância e componentes nas regiões brasileiras entre 2010 e 2016. In: Saúde Brasil 2018: uma análise de situação de saúde e das doenças e agravos crônicos: desafios e perspectivas. Brasília: Ministério da Saúde; 2019. p. 33-58.

3. Victora CG, Aquino EM, Do Carmo Leal M, Monteiro CA, Barros FC, Szwarcwald CL. Maternal and child health in Brazil: progress and challenges. Lancet. 2011;377(9780):1863-76. https://doi.org/10.1016/S0140-6736(11)6013 $8-4$

4. United Nations. Transforming our world: the 2030 agenda for sustainable development. New York: United Nations; 2015.

5. Vergnano S, Sharland M, Kazembe P, Mwansambo C, Heath P. Neonatal sepsis: an international perspective. Arch Dis Child Fetal Neonatal Ed. 2005; 90(3):220-4.

6. Simonsen KA, Anderson-Berry AL, Delair SF, Davies HD. Early-onset neonatal sepsis. Clin Microbiol Rev. 2014;27(1):21-47. https://doi.org/10.1128/CMR. 00031-13

7. Downey LC, Smith PB, Benjamin DK Jr. Risk factors and prevention of lateonset sepsis in premature infants. Early Hum Dev. 2010;86(Suppl 1):7-12. https://doi.org/10.1016/j.earlhumdev.2010.01.012.

8. Prade SS, Oliveira ST, Rodriguez R, Nunes FA, Félix JK, Pereira $M$, et al. Estudo brasileiro da magnitude de infecções hospitalares em hospitais terciários. Revista do Controle de Infecção Hospitalar. 1995;2:11e24.

9. Brasil. Lei n 9.431, de 6 de Janeiro de 1997.

10. Padoveze MC, Assis DB, Freire MP, Madalosso G, Ferreira SA, Valente MG, et al. Surveillance Programme for healthcare associated infections in the state of São Paulo, Brazil. Implementation and the first three years' results. J Hosp Infect. 2010;76(4):311-5. https://doi.org/10.1016/j.jhin.2010.07.005.

11. Brasil. Agência Nacional de Vigilância Sanitária. Boletim de Segurança do Paciente e Qualidade em Serviços de Saúde nº 05: Indicador de Infecção Primária de Corrente Sanguínea: Análise dos dados das Unidades de Terapia Intensiva Brasileiras no ano de 2011. Brasília: ANVISA; 2012.

12. RIPSA - Rede Interagencial de Informações para a Saúde. Proporção de partos hospitalares. http://www.ripsa.org.br (2012). Accessed 20 March 2020.

13. Moher D, Shamseer L, Clarke M, Ghersi D, Liberati A, Petticrew M, et al. Preferred reporting items for systematic review and meta-analysis protocols (PRISMA-P) 2015 statement. Syst Rev. 2015;4(1):1. https://doi.org/10.1186/204 6-4053-4-1.

14. Barendregt JJ, Doi SA. MetaXL User Guide version 5.3. 2016. http://www. epigear.com/index_files/MetaXL\%20User\%20Guide.pdf. .

15. Barendregt JJ, Doi SA, Lee YY, Norman RE, Vos T. Meta-analysis of prevalence. J Epidemiol Community Health. 2013;67(11):974-8. 
16. Kawagoe JY, Segre CA, Pereira CR, Cardoso MF, Silva CV, Fukushima JT. Risk factors for nosocomial infections in critically ill newborns: a 5-year prospective cohort study. Am J Infect Control. 2001;29(2):109-14.

17. Nagata E, Brito AS, Matsuo T. Nosocomial infections in a neonatal intensive care unit: incidence and risk factors. Am J Infect Control. 2002;30(1):26-31. https://doi.org/10.1067/mic.2002.119823.

18. Pessoa-Silva CL, Richtmann R, Calil R, Santos RM, Costa ML, Frota AC, et al. Healthcare-associated infections among neonates in Brazil. Infect Control Hosp Epidemiol. 2004;25(9):772-7. https://doi.org/10.1086/502475.

19. Couto RC, Carvalho EA, Pedrosa TM, Pedroso ER, Neto MC, Biscione FM. A 10-year prospective surveillance of nosocomial infections in neonatal intensive care units. Am J Infect Control. 2007;35(3):183-9.

20. Távora AC, Castro AB, Militão MA, Girão JE, Ribeiro Kde C, Távora LG. Risk factors for nosocomial infection in a Brazilian neonatal intensive care unit. Braz J Infect Dis. 2008;12(1):75-9. https://doi.org/10.1590/S1413-86702 008000100016

21. Pereira SM, de Almeida Cardoso MH, Figuexeds AL, Mattos H, Rozembaum R, Ferreira VI, et al. Sepsis-related mortality of very low birth weight Brazilian infants: the role of Pseudomonas aeruginosa. Int J Pediatr. 2009;2009: 427682

22. Catarino CF, Martins ACS, Silva APAM, Gomes AVO, Nascimento MAL. [Epidemiological Profile of Primary Bloodstream Infections in Neonatal Intensive Care Unit]. R. pesq.: cuid. fundam. online. 2012;(1):3229-37.

23. Dal-Bó K, Silva RM, Sakae TM. Nosocomial infections in a neonatal intensive care unit in South Brazil. Rev Bras Ter Intensiva. 2012;24(4):381-5. https://doi. org/10.1590/S0103-507X2012000400015.

24. Freitas BA, Peloso M, Manella LD, Franceschini Sdo C, Longo GZ, Gomes AP, et al. Late-onset sepsis in preterm children in a neonatal intensive care unit: a three-year analysis. Rev Bras Ter Intensiva. 2012;24(1):79-85. https://doi. org/10.1590/S0103-507X2012000100012.

25. Ventura CM, Alves JG, Meneses JA. Adverse events in a neonatal intensive care unit. Rev Bras Enferm. 2012;65(1):49-55. https://doi.org/10.1590/S003471672012000100007.

26. Romanelli RM, Anchieta LM, Mourão MV, Campos FA, Loyola FC, Jesus LA, et al. Notification of healthcare associated infections based on international criteria performed in a reference neonatal progressive care unity in Belo Horizonte, MG. Rev Bras Epidemiol. 2013;16(1):77-86. https://doi.org/10.1 590/S1415-790X2013000100008.

27. da Silva AR, Simões ML, Werneck Ldos S, Teixeira CH. Healthcare associated infections caused by coagulase-negative staphylococci in a neonatal intensive care unit. Rev Bras Ter Intensiva. 2013;25(3):239-44. https://doi. org/10.5935/0103-507X.20130041.

28. de Souza Rugolo LM, Bentlin MR, Mussi-Pinhata M, de Almeida MF, Lopes JM, Marba ST, et al. Late-onset sepsis in very low birth weight infants: a Brazilian neonatal research network study. J Trop Pediatr. 2014;60(6):415-21. https://doi.org/10.1093/tropej/fmu038.

29. Urzedo JE, Levenhagen MM, Pedroso RS, Abdallah VO, Sabino SS, Brito DV. Nosocomial infections in a neonatal intensive care unit during 16 years: 1997-2012. Rev Soc Bras Med Trop. 2014;47(3):321-6. https://doi.org/10.1 590/0037-8682-0101-2014.

30. Freitas FTM, Araujo AFOL, Melo MIS, Romero GAS. Late-onset sepsis and mortality among neonates in a Brazilian intensive care unit: a cohort study and survival analysis. Epidemiol Infect. 2019;147:e208. https://doi.org/10.101 7/S095026881900092X.

31. Brasil. Agência Nacional de Vigilância Sanitária. Boletim Informativo: Segurança do Paciente e Qualidade em Serviços de Saúde n²0. Avaliação dos indicadores nacionais de IRAS e RM 2018. Brasília: ANVISA; 2020. https:// www20.anvisa.gov.br/segurancadopaciente/index.php/publicacoes/item/ boletim-seguranca-do-paciente-e-qualidade-em-servicos-de-saude-n-20incidentes-relacionados-a-assistencia-a-saude-2018.

32. Rosenthal VD, Al-Abdely HM, El-Kholy AA, Aziz Alkhawaja SA, Leblebicioglu $H$, Mehta $Y$, et al. International nosocomial infection control consortium report, data summary of 50 countries for 2010-2015: device-associated module. Am J Infect Control. 2016;44(12):1495-504. https://doi.org/10.1016/ j.ajic.2016.08.007

33. Hocevar SN, Edwards JR, Horan TC, Morrell GC, Iwamoto M, Lessa FC. Device-associated infections among neonatal intensive care unit patients: incidence and associated pathogens reported to the National Healthcare Safety Network, 2006-2008. Infect Control Hosp Epidemiol. 2012;33(12): 1200-6. https://doi.org/10.1086/668425.
34. Leistner R, Piening B, Gastmeier P, Geffers C, Schwab F. Nosocomial infections in very low birth weight infants in Germany: current data from the National Surveillance System NEO-KISS. Klin Padiatr. 2013;225(2):75-80. https://doi.org/10.1055/s-0033-1334886.

35. Brasil. Agência Nacional de Vigilância Sanitária. Boletim de Segurança do Paciente e Qualidade em Serviços de Saúde n 17. Avaliação dos indicadores nacionais das infecções relacionadas à assistência à saúde (IRAS) e resistência microbiana do ano de 2017. Brasília: ANVISA; 2019. https:// www20.anvisa.gov.br/segurancadopaciente/index.php/publicacoes/item/ boletim-seguranca-do-paciente-e-qualidade-em-servicos-de-saude.

36. Horan TC, Andrus M, Dudeck MA. CDC/NHSN surveillance definition of health care-associated infection and criteria for specific types of infections in the acute care setting. Am J Infect Control. 2008;36(5):309-32. https://doi. org/10.1016/j.ajic.2008.03.002

37. Brasil. Agência Nacional de Vigilância Sanitária (ANVISA). Critérios Diagnósticos de Infecção Associada à Assistência à Saúde - Neonatologia. 2nd ed. Brasília: ANVISA; 2017.

38. Doi SA, Barendregt JJ, Khan S, Thalib L, Williams GM. Advances in the Metaanalysis of heterogeneous clinical trials II: The quality effects model. Contemp Clin Trials. 2015;45(Pt A):123-9.

39. Stone JC, Glass K, Munn Z, Tugwell P, Doi SAR. Comparison of bias adjustment methods in meta-analysis suggests that quality effects modeling may have less limitations than other approaches. J Clin Epidemiol. 2020;117: 36-45. https://doi.org/10.1016/j.jclinepi.2019.09.010.

40. Ferrari AJ, Sukanta S, McGrathet JJ, Norman R, Baxter AJ, Vos T, et al. Health states for schizophrenia and bipolar disorder within the global burden of disease 2010 study. Popul Health Metrics. 2012;10(1):16. https://doi.org/10.11 86/1478-7954-10-16

41. Fitchett EJ, Seale AC, Vergnano S, Sharland M, Heath PT, Saha SK, et al. Strengthening the reporting of observational studies in epidemiology for newborn infection (STROBE-NI): an extension of the STROBE statement for neonatal infection research. Lancet Infect Dis. 2016;16(10):e202-13. https:// doi.org/10.1016/S1473-3099(16)30082-2.

42. Silveira MF, Santos IS, Barros AJ, Matijasevich A, Barros FC, Victora CG. Increase in preterm births in Brazil: review of population-based studies. Rev Saude Publica. 2008;42(5):957-64. https://doi.org/10.1590/S0034-89102 008000500023.

43. Delnord M, Mortensen L, Hindori-Mohangoo AD, Blondel B, Gissler M, Kramer MR, et al. International variations in the gestational age distribution of births: an ecological study in 34 high-income countries. Eur J Pub Health. 2018;28(2):303-9. https://doi.org/10.1093/eurpub/ckx131.

44. Betrán AP, Ye J, Moller AB, Zhang J, Gülmezoglu AM, Torloni MR, et al. The increasing trend in caesarean section rates: global, regional and national estimates: 1990-2014. PLoS One. 2016;11(2):e0148343. https://doi.org/10.13 71/journal.pone.0148343.

45. Zaidi AK, Huskins WC, Thaver D, Bhutta ZA, Abbas Z, Goldmann DA Hospital-acquired neonatal infections in developing countries. Lancet. 2005; 365(9465):1175-88. https://doi.org/10.1016/S0140-6736(05)71881-X.

\section{Publisher's Note}

Springer Nature remains neutral with regard to jurisdictional claims in published maps and institutional affiliations.

Ready to submit your research? Choose BMC and benefit from

- fast, convenient online submission

- thorough peer review by experienced researchers in your field

- rapid publication on acceptance

- support for research data, including large and complex data types

- gold Open Access which fosters wider collaboration and increased citations

- maximum visibility for your research: over $100 \mathrm{M}$ website views per year

At $\mathrm{BMC}$, research is always in progress.

Learn more biomedcentral.com/submissions 